\title{
Whose Idea Was it Anyway?
}

\author{
Marlene Nourbese Philip
}

\section{Qui a eu l'idée?}

Cette fiction théorique explore le lien entre le patriarcat et l'esclavagisme en personnifiant le créateur de cet ignoble commerce des êtres. Cette personne, tout comme Christophe Colomb ou Adolf Hitler, est entrée dans l'histoire pour l'avoir marquée. Il faut préciser que sous forme résumée le texte perd sa subtilité et devient plus choquant.

$D u$ foyer ardent au bureau, du bureau au foyer, un Européen du quinzième siècle fait les cent pas dans cette opulente pièce; une pièce qui lui jette au visage son prestige, sa stabilité, sa richesse. Il vient d'avoir une idée d'une ampleur telle que la tête lui tourne autant qu'il fait tourner son globe terrestre ... Réveille-t-il sa femme pour lui en parler? La raconte-t-il à ses enfants? L'annonce-t-il avec fierté à ses confrères? En inscrit-il la date dans son journal intime? Note-il sa solution brillante à la pénurie de main-d'oeuvre dans le Nouveau Monde, une main-d'oeuvre décimée par la méfiance et la maladie? Onn'en sait rien. Son idée: l'esclavagisme ne serait que la suite logique de l'esprit messianique du christianisme à l'oeuvre dans les croisades; corollairement, la transsubtantiation - le changement d'une substance en une autre, $d u$ pain et du vin en chair et en sang-illustrele passage du corps et du sang en espèces, biens mobiliers, effets. Toute transaction implique d'inévitables pertes, la traite des noirs n'échappe pas à cette loi (Cuffee, un Africain dans la trentaine, se jetteà la mer; Ayo, une noire très belle, meurt subitement); mais également elle peut générer des profits énormes.

Sa peau noire luit au-dessus de lui à la lumière d'une bougie, des perles de sueurembellissent ses seins.Ill'attire vers luiet la pénètre profondément. C'est une servante, la domestique de sa femme, une sauvagesse, mais il la désire plus que toute autre femme. Parce qu'il ne peut maîtriser ses sentiments pour elle, il la déteste. Son désir de la dominer, de la transformer en objet, pourrait expliquer son besoin d'exhorter des hommes d'affaires, habituellement conservateurs, à prendre le risque 
d'investir dans diverses compagnies européennes en Afrique (par exemple, la Compagnie royale des aventuriers).

Dans ses rêves elle s'approche de lui, tenant dans ses bas, l'enfant de leur amour. Elle pleure et elle implore sa pitié ... et il en est satisfait.

Le feu s'éteint, et la lumière rougeoie sur sa silhouette, saigne sur sa joue, recouvrant sa peau d'un éclat sanguinolant. Il a les yeux bleus, la peau est les cheveux clairs, et un fou rire l'envahit.

From fireplace to desk - up and down - round and round - first the desk, next the room - back to the fireplace again he paces. The room is large, well appointed with furnishings that underscore and emphasize the owner's stability and comfort - his wealth even. Velvets; brocades; the gleam of polished wood; silver, even some gold, are all in abundance. Before the fireplace is the rug, in all likelihood Persian, but certainly of the Orient; theintensity and depth of its colours: red, sepia, burnt sienna, beige and black are held in perfect balance by its intricate patterning. It muffles his footsteps, provides further evidence, if any is needed, of wealth.

On the panelled walls hang paintings which further bespeak their owner's station in life. The fire's energy is caught and reflected in the occasional glint of gold leaf that frames the novelty and lustre of the still-new medium, oil. Portraiture: a group of plump women in diaphanous clothing; still life: a bottle of wine - the darkest of green luminescent, a glass, some fruit with the sheen of freshness still upon them, pastries ... all eternally ready to be consumed; landscape: a hayfield and in it a hayrick silhouetted against a red setting sun; classicism: Actaeon fleeing his hounds and the beautiful Artemis; biblical:a woman - Mary Magdalene - in deep meditation, her hand upon a skull; every genre is represented. There are, as yet, no Raphaels, Titians, or da Vincis; no Pisanellos or Caravaggios; those will undoubtedly come later. For the present these are the lesser works of lesser masters, and their illusion is better served by the firelight. Their purpose is to reflect back to him who paces, as nothing else does, his solidity, his wealth, his burgeoning power - his being.

The desk, fashioned from a dark wood - mahogany perhaps - and richly coloured, faces the fireplace; its polished surfaces gleam in the fire and lamp light. As befits the man who paces, it is a large desk; on it rests a globe-a Martin Behaim globe-a hymn book, a psalter, a book of arithmetic and Ptolemy's Geographia. 
Every so often the man interrupts his pacing to stand before the globe, and, with the tip of his right index finger he sets it spinning gently almost at first - only to increase its speed until its outlines are a mere blur. He laughs. Abruptly he uses the flat of his palm to stop the revolutions - the globe shudders and trembles under the impact of the sudden arrest.

Can we put an exact date to the man's pacing? A time? The fireand the light through the window suggest a dying day. Did he, that morning, leap out of bed with an exclamation, a shout as of surprise or discovery - of excitement? He might perhaps have echoed Archimedes-

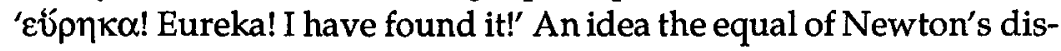
covery of the principle of universal gravitation; Galileo's discovery of the Milky Way; Copernicus' centring the motionless sun at the heart of our galaxy; the 'cogito ergo sum' of Déscartes. Such an idea, such a thought, such a plan that would - but as yet he had no idea of its enormous potential.

Who was he? A man, of course. Neither peasant nor serf - a nobleman perhaps - possibly a lord. Would a nobleman have sullied his thoughts with an idea so crass, yet so utterly brilliant? Spanish, Portuguese, English, French - was heany of these things? Does it matter? He was European - undoubtedly manifesting the European mind long before the word 'European' would come into vogue. Some no doubt called him blessed - a genius; generations of mothers' sons and daughters would curse him, unknown that he was, into eternity. Too many and too few would die; too many and too few live out the diabolical plan that would change the world to come ... and forever. Philosophy, medicine, jurisprudence, economics - no discipline would be left untouched; anthropology and craniology - new branches of knowledge would develop to manage the unmanageable.

Was it an idea that was solely his, or were there several like him, within his own nation and without, who would serendipitously conceive and nurture the same idea at the same time? An outburst - a veritable epidemic - of synchrony; a natural effervescence within national psyches that collectively manifested itself in these isolated instances of Promethean thought.

Were they all men who had risen with the morning sun from their beds of linen sheets, laundered by the many hands of their many female servants; men who had then washed themselves perhaps, dressed or were dressed - noblemen or good solid burghers; mer- 
chants with an eye for profit? Did they then shake their wives awake and, with a quietly controlled excitement, say in unison: 'Listen my dear; écoute ma femme; oiga mi esposa; listen, listen, I have an idea,' or perhaps, 'I had a dream ... last night ... a dream, a cauchemar in which I saw one hundred thousand ships ... at anchor ... under sail ...'

They - these women - would have listened, as they had always listened to everything their husbands had to say - eyes widening under the import of what he told them - the brilliant simplicity of it all - seeing in their mind's eye larger houses, mansions perhaps, more servants, gold, jewels. Such an idea! And did he, did they then, wives and husbands all, embrace their children, flaxen or dark-haired, downy skin still damp and soft with sleep? Did he caress their youth, their innocence - their years not yet burdened with age, with doubt ... with ideas, the infinity in their gaze turned toward history-not saying much, but transferring to them his excitement - his sin perhaps? Or was it merely business?

Did he not circle? no - that would come later, but did he not note the date, record it in his diary as he would have any event on his freehold estate, or at his business? On such and such a day, in the year of our Lord, I conceived - no-the idea came upon me-no-Isaw clearly how - ... On the sixth day of January, fifteen hundred and thirty five, A.D., he might have written, or if he wished to reveal his learning, anno domini, or le huitième jour d'Août, the fourteenth day of March, fifteen hundred and two, in the year of our Lord - he could just as easily have written fifteen hundred and three, fifteen hundred and twelve or fifteen hundred and sixteen - I sat at my desk, he would have continued, or, walked in my garden admiring the roses of an evening; I sat drinking port after dinner on the evening of ...; just before I rose from my bed ...; while at prayers in the chapel ... as the reverend father ... during the Te Deum Laudamus, or was it the Nicene Creed ... a blinding flash of light, a sound as of rushing wings or water, a low murmur ... almost ... a susurration of voices ... a clap of thunder and there it was - the idea. A brilliant insight it might have been called four centuries later-likeEinstein's ... mineeyes have seen ... the fusion of past, present, and future - change ...

It would have wanted for any competition - an idea such as this had it been nurtured amid smoke, grime and filth, its brilliance and luminescence lighting up, between the picking and killing of fleas, ticks and other vermin, the hovel that wombed it. It demanded light, however, space, leisure ... it demanded wealth. 
Wheresoever it happened to have been conceived, it deserved to have been reported, recorded, annotated, copyrighted, data banked, chiselled in stone: on __ the _ day of _ , fifteen hundred and whatever, or maybe it was fourteen hundred (the Portuguese had a monopoly by 1450 ), but certainly no later than fifteen hundred and eighteenwe know the Spanish crown sanctioned the idea in that year - and most certainly in the year of our Lord.

Board rooms, flow charts, bottom lines - an advertising campaign to rival Coke's and Pepsi's; an idea of such magnitude - in today's world - would call for no less than these, its purveyors pin-striped, tailored - male and female both - blonde, blue-eyed and Christian, for that was the linch pin of the idea. The full and dark flowering of the messianic, crusading spirit of Christianity.

Idea: archetype, pattern, plan, standard of perfection; an idea the plan or design according to which something is created or constructed -1581 .

What was the idea? To prevent further genocide of the Indian (according to Bartholomew de las Casas)? To obtain a cheap source of labour? To convert from human to thing, pagan to Christian, the African?

Transubstantiation: the changing of one substance into another, bread and wine into body and blood ... body and blood into thing, chattel, meuble, cosa.

The bowels of each sailing ship designed for non-human cargo would entomb approximately three hundred Africans per voyage in their own stench and filth for however long it took to sail the AtlanticLiverpool to the Gold Coast to the Caribbean and back to Liverpool. Equilateral triangle of trade and death. Some estimate as many as fifteen million Africans were brought across the Atlantic. And there are those who say one was too many.

'Gentlemen, we estimate that on each voyage some of your cargo will be lost - this is unfortunate ... and inevitable, but I believe, nay am confident that we can more than recover all of our expenses through our price per chattel at the auction block. I caution you, however, to be very careful when selecting Black ivory for the voyage - bevery certain to choose the fittest and strongestit is the only way to minimize your losses and maximize your profits. If you pack closely enough, each of our sailing ships could hold some four hundred pieces of the Indies, here, you can see for yourselves, I have sketched a picture of how they would lie for maximum use of your space.' 
Black ivory; pieces of the Indies; the idea skulks and hides behind euphemisms.

'But be prepared for losses.'

Cuffee African man of some 30 years - jumped overboard

Quesaba Negro woman of undetermined years - died this day of wasting illness

Quarshie Negro man of some 30 years - passed away from dropsy

Abena Very young woman - under 20 years - taken suddenly by fever

Jumpke Husband to Abena-consumption, worms, and ague

Obafemi Negro boy no more than seven years - ague

Ayo Negro woman-very beautiful-departed this life suddenly

Bem depted this life on account of convulsion and fits

Did the idea encompass minutiae such as these, or did its purveyor think in broader strokes? the repopulating of not one but two continents recently decimated of its indigenous populations; or of profits: hundredweights of sugar and tobacco, tons of slaves.

'You see, gentlemen,' he strode upand down the room, 'I have, without doubt, ascertained that the Old World cannot populate the New-'Hehas all of their attention now, these well-fed, well-clothed gentlemen sitting around his table nursing their port as he nurses their captured attention. 'Simply put, there are not enough of us.' A low mutter of concern ripples around the table. 'Here on these spread sheets you may see quite clearly what the population of the Old World is. Our computer projections confirm that there is not one but two continents for the taking, but weneed people. People! Bodies! Unfortunately the indigenous populations have proven unequal to the task ... succumbed to illnesses, indulged in useless warfare -' A murmur of discontent and complaint eddies around him.

"The sine qua non of the development of these areas captured from the heathen and held in the name of our sovereign is the blackamoor, the African if you will. There is nothing which contributes more to the development of the colonies and the cultivation of their soil than the laborious toil of the Negroes - Negro slaves are the strength and sinews of ourNew World. About that Iam certain.' The murmur of approval swirls around the table. 'Now gentlemen,' he got to his feet abruptly, 'a toast, I propose a toast,' raising his glass and in so doing spilling some of its dark red contents onto the polished surface of the table. 
'A toast! a toast!' The words echo around the table as the men get to their feet and hold up their glasses, the cut crystal refracting the lights from many lamps, the dark red liquid in each glass glowing preternaturally as the light is first trapped by it and then released.

'Magnum est saccarum et prevalebit! Great is sugar, and it will prevail!'

'Great is sugar,' they all replied.

'To Black Ivory, Pieces of the Indies, and the Negro! To our profits!'

'Here, here!' There was laughter; the mood had lightened and was almost celebratory.

The black skin gleamed softly above him in the candle light, tiny globules of sweat beading herbreasts. In the muted light it was as if she wore a necklace of crystals, as if she had been dusted all over with crystal droplets. Roughly he buried his fingers in the short cap of hair that curled and clung to herscalp.

'The idea, gentlemen, however, is to populate the continent with workers who have proved themselves able to withstand the work and the heat with minimal costs to their owners. Furthermore, these people are also savages, pagans who have no God. We can Christianize them at the same time as they produce our sugar, our tobacco and our cotton.'

'Surely once they become Christians we can nolonger enslave them -isn't that gainsaying the teachings of the Good Book?'

The man addressing them smiles. 'We shall address that problem if and when it does arise. Until such time our success is assured, gentlemen.' They nodded in agreement.

She had tormented him for months with her body - nothing but a servant - a maid to his wife ... a savage really. The woman sat astride him, they both panted, she bit on her underlip drawing blood; he reached up and pulled her down so that she half lay, half sat on him his penis lodged deep within her. She washed, cleaned and served them, but oh how he wanted her! Like he had never wanted or desired his wife ... like he had never wanted anyone, or anything for that matter, before or since. And for that reason he hated her, could not reason her away: her smell, her touch. The taste of her! She made him do things he did not want to do and having done them he wished to repeat them again and again. Things that he had to do, made him no better than a rutting beast in the fields - like she was. Brought him to his knees before her, her beauty and ... their love. The word had risen unbidden to his thoughts and he felt himself flush ... with shame? embarrassment? He loved a savage! 
'Gentlemen, I have worked out the figures here-our expenses will be increased because we need to erect and maintain forts to protect our enterprises but at one hundred cowrie shells per head - we may need to include weapons like the Birmingham gun - plus the cost of transportation, and allowing for some loss of cargo, we should be making a profit of one hundred dollars per piece of Black ivory. That is a conservative estimate gentlemen!' His audience smiles and nods in approval; general conversation has broken out around the table. He holds up his hand which commands silence: 'Companies are essential to the protection and maintenance of our capital, gentlemen, and we must get to work immediately setting them up.'

A plethora of companies: The English Guinea Company, The Senegal Company, The Royal African Company, The British West India Company, The Company of Royal Adventurers, The French West India Company, The Dutch West India Company, The Guinea Company. Each and every one devoted to the idea and ideal of treating human beings as chattels.

Transubstantiation: the changing of one substance into another. Bread and wine into body and blood, body and blood into thing, chattel, meuble, cosa, thing.

Was that where the idea started? To make her a thing-less than he? Less than human. So that he could control her ... and himself. Did that explain his fervour in getting this plan started? urging these ordinarily cautious, respectable men to get involved - risk! invest! He always managed to control thoughts such as these. Except in his dreams where she comes holding her child - savage - his child-half-savage their child ... of their love, crying and begging his mercy and generosity ... begging ... as she should.

The Bishop strongly recommends that when cargoes of Negro slaves arrive in the harbour, priests should immediately be assigned to instruct them in the Christian faith and to teach them the doctrine of the Church in order to baptize them, and also to see to it that the Negroes hear Mass and go to confessions and communion. ${ }^{1}$

Surely the progenitor and architect of this idea - if we could but identify him - should take his place alongside those who, like the Portuguese navigators, Cristobal Colon, or Adolf Hitler, have stood in the way of history and altered it. 
It was a truly wonderful sight to see them all standing there, for some were fairly white and well-formed, some were as yellow as mulattoes, and some were as black as Ethiopians ... But who would have been so hard of heart as not to feel pity for them in their distress! Some lowered their tear-splashed faces, others bewailed themselves loudly and turned their eyes to the heavens, and still others struck themselves in the face and threw themselves to the ground. There were those who sang lamentations, and although we did not understand the words, the melodies told of their great sorrow ...2

Maybe the idea was happenstance, developed by small accretions of practice - $\mathbf{a}$ few here, a few there-as gradual as a meandering river gracefully yet inexorably eroding a shoreline. An idea that was merely the result of the accumulation of capital needing to expand-to create new markets:

... it is no less than four months since traders took five hundred from Cape Verde to New Spain in one boat, and one hundred and twenty died in one night because they packed them like pigs or even worse, all below decks, where their very breath and excrement (which are sufficient to pollute any atmosphere and destroy them all) killed them. It was indeed ajust punishment from God that these brutal men who were responsible for carrying them also died. The sad affair did not end there, for before they reached New Mexico almost three hundred died. ${ }^{3}$

A phenomenon of such gargantuan proportions and scale must have been deliberately conceived. By someone, somewhere, sometime: the man stands before the globe; his arms are folded, his head lowered as if in thought. Suddenly he throws his head back, exposing a smooth and cleanly shaved white throat, and laughs again and again. When he stops he sets the globe spinning again with his finger... waits for the speed of its revolutions to lessen, and with a gentle motion - a caress almost - he brings the globe to a halt. Lightly, at first haltingly, he traces his right index finger down along the newly opened Indian ocean, around - the finger moves more surely now - Bartholomeu Dias' discoveries at the Cape of Good Hope, up ... along the west coast and across - now his finger is fully confident - the varnished ocean, painted blue ... to a new world not yet discovered, but which he would help to birth. 


\section{$54 \cdot$ Tessera}

The fire is dying now; its light reddens the outline of his robe all along his right side, bleeds on to his right cheek painting his skin with a sanguinary glow as it embraces his head with its fiery corona. It is hard to tell in the dim light, but his eyes are blue, like the painted ocean, his hair is blonde, his skin fair, and he laughs again and again.

\section{Notes}

1. Father Daimen Lopez de Haro, Bishop of San Juan, Report to a Diocesan Synod, San Juan, April 30 - May 6, 1645.

2. Gomes Eannes de Azurara, Portuguese chronicler (1410-1474) Cronica de Descobrimento e Conquista de Guine.

3. Fray Tomas Mercado, Suma de Tratos y Contratos, Seville (1587). 